\title{
BURSA CITY MUSEUM FROM PAST TO THE PRESENT
}

\author{
Muna SİLAV \\ Gazi University, Turkey \\ muna@gazi.edu.tr
}

\begin{abstract}
Museums are places that transfers social, economic and cultural heritage from past to present. Society' lifestyle, traditions, and habits are memory of the city. Regarded as exhibiting the cultural values of the past and the city's memory, the museums carry the characteristics values of society and value judgments. Playing an important role in the formation of Turkish culture and keeping it alive the city of Bursa has protected its historic heritage until the present day. This city, which was capital of the Ottoman Empire for many years, is one of the centers of rich culture and civilization. With a reputation, especially as a center of sericulture and weaving, Bursa is also has a unique historical heritage along with its inns, spas, shrines, public baths and fountains and many original structure belong to Republican period. Bursa City Museum is an institution that exhibits documenting the social development of the city throughout history. The purpose of this study is to evaluate the place and content of Bursa City Museum, which is open to the public, in society.
\end{abstract}

Keywords: Museum, City Museum, Bursa City Museum

\section{INTRODUCTION}

Museum is an important educational institution that reflects the cultural and scientific background of society and which researches, collects, preserves, exhibits, and delivers these values (Tezcan Akmehmet\&Ödekan, 2006). This space, which supports the cultural interaction between communities, transfers concrete descriptions of history to future generations. Museum is not only an institution that exhibits its collection, but also it is a center which supports research efforts, organizes some exhibitions about various topics and preserves cultural heritages in which ideas are shared (Vardar, 1998). Besides being the identity of society, they are places where ideas, beliefs, behaviors, and lifestyles have been found and have been transmitted from past to future. Great development in industrialization and urbanization in time, and factors like social-economic and cultural changes have affected the development of museums. This interaction have provided to give importance and to preserve the values that have been lost with cultural heritage (Silier, 2010). Being a factor of various fields in the society, museums that aim the protection of monuments have formed actively contributing units. The purpose of the first years of museums was to collect, to exhibit and to report historical data. Along with the development of education and training, settlement of the phenomenon of aesthetic, the interpreting the past and present with explanations, directing changes in society are also added to these aims (Eldem\&Gökhan, 1992).

\section{CITY MUSEUM}

City museums reflects the historical process of the city from past to present. They are institutions that transmit the city's social structure neighborhood culture and the traditional concept of community to future generations. It is the pioneer to studies that are done for a better recognition of the city and for protection of cultural heritage. It is a communication and culture center providing social unity developing respect and empathy (Silier, 2010). Values of tangible and intangible cultural heritage create identity and cultural heritage of communities. In order to preserve the heritage of cultural and natural heritage firstly this heritage must be determined and certified. These museums allow the formation of new communication networks that will provide accurate reading of the urban heritage protection and urban existence, by preparing a breakdown of the city's cultural heritage. It also performs visual history writing (Collins, 1995) (Madran 2001). 
The purpose of the individuals to live in a city creates the city's concept of memory. By the keeping traditional tissue (such as promotion of traditional handicrafts, keeping them alive and transforming them to the future generations) alive the memory loss can be prevented. That people's living strengthening relations with each other and city is an indication of the continuity of life in the city. Foundations of museums that provide information about the history of the cities were held in Bursa, Antalya, Kastamonu, Kayseri, and İzmir (Silier, 2010) (Madran 2000).

\section{BURSA CITY MUSEUM}

Bursa City Museum was opened in 2004 with the understanding of "The Living City, Living Museum" in the old Courthouse Building. It is an institution that investigates, protects, and exhibits works to educate and develop the community. Belonging to the Republican Period, conducted in 1925-1926, I. The National Architectural structures Courthouse Building, is located in an officially registered cultural space. This field, defined as a cultural space in the city development plan, is located in the city center and it is at a point that is easily accessible (Cengiz, 2009).

In the Bursa City Museum, the city's historical, geographical, commercial, socio-economic, and cultural values are represented in chronological order of presentation. Passing into the hands of the Turks in 1326 by Mr. Orhan, and representing being capital of Ottoman Empire, urban planning process began in Bursa with the Republican era. With the development of industry and immigration starting in 1960's, the city's population and urban development has changed rapidly. Today, with the increasing of its geographic location, agricultural, commercial, and industrial capacity the increasing importance of Bursa city has been emphasized in this museum. Configured different patterns compared to traditional museum in terms of both content and format, the museum contains chronological order on the ground floor and thematic narrative. Starting from mound Ilipınar what is remained from BC. 6000 and occurred in Bursa region urban development of Bursa is exhibited in (Anonymity, 2008). The first gallery, which is on the ground floor of Bursa City Museum that consists of three floors, carries the name of "Bursa city of Civilizations." The first civilizations in and around Bursa, consists information about the Bursa that is in the time of War of Independence and Ottoman period. Named as "Contemporary Bursa", the second gallery describes the historical process from the Republican Period to the present (Figure 1).
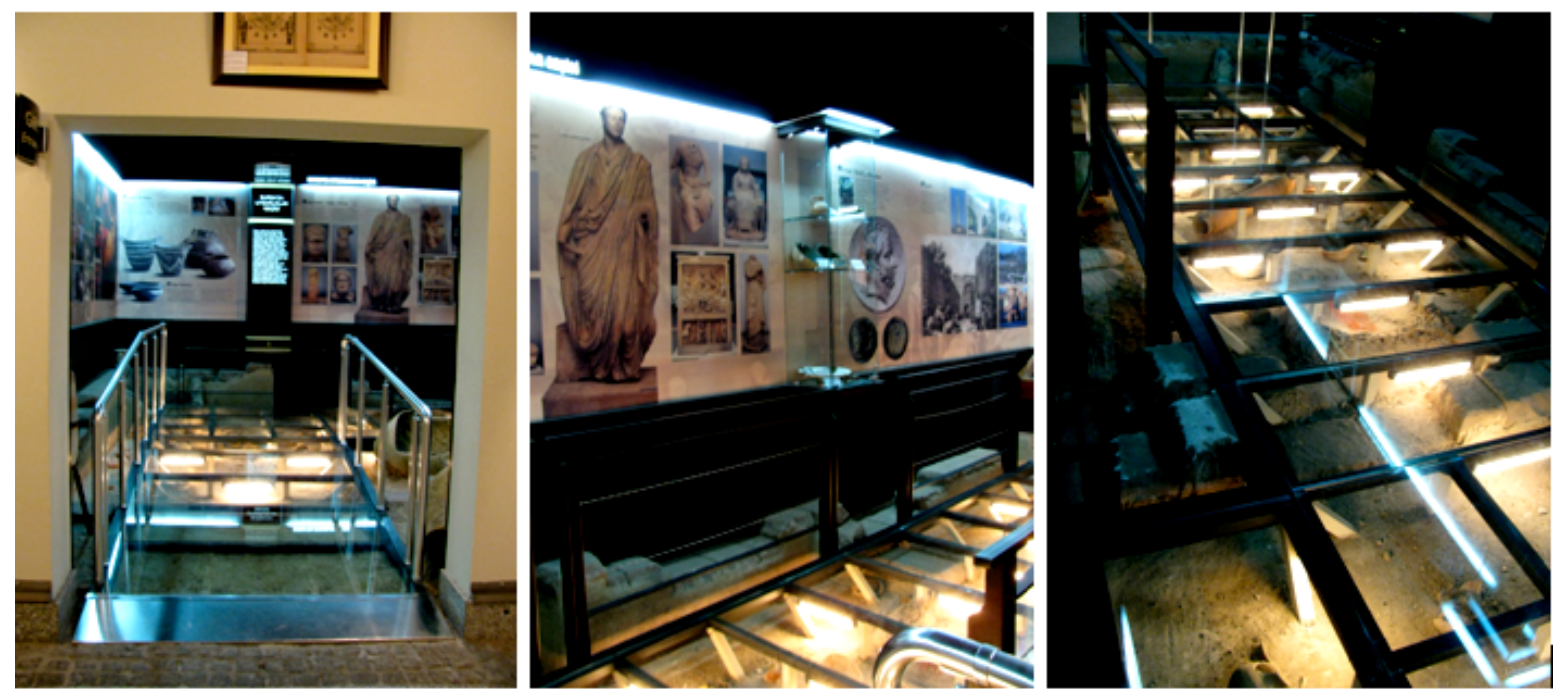

Figure 1: Bursa City Museum, Exhibition Area at Entrance Floor

(Photograph:Muna Silav) 
In the museum, the six wax statues of Ottoman sultans' (who lived in Bursa) are also included (Figure 2). Topographical model of the city of Bursa in the museum gives information about monument works such as Bursa walls, complexes, commercial buildings, baths, and mosques (Figure 3). Besides the exhibition spaces there is an area on the ground floor of the museum that visitors can relax and also a gift shop sales unit is included. At the same time, the museum has the spatial equipment, which provides individuals with disabilities visit the museum. (Ramps, disabled toilets, etc)
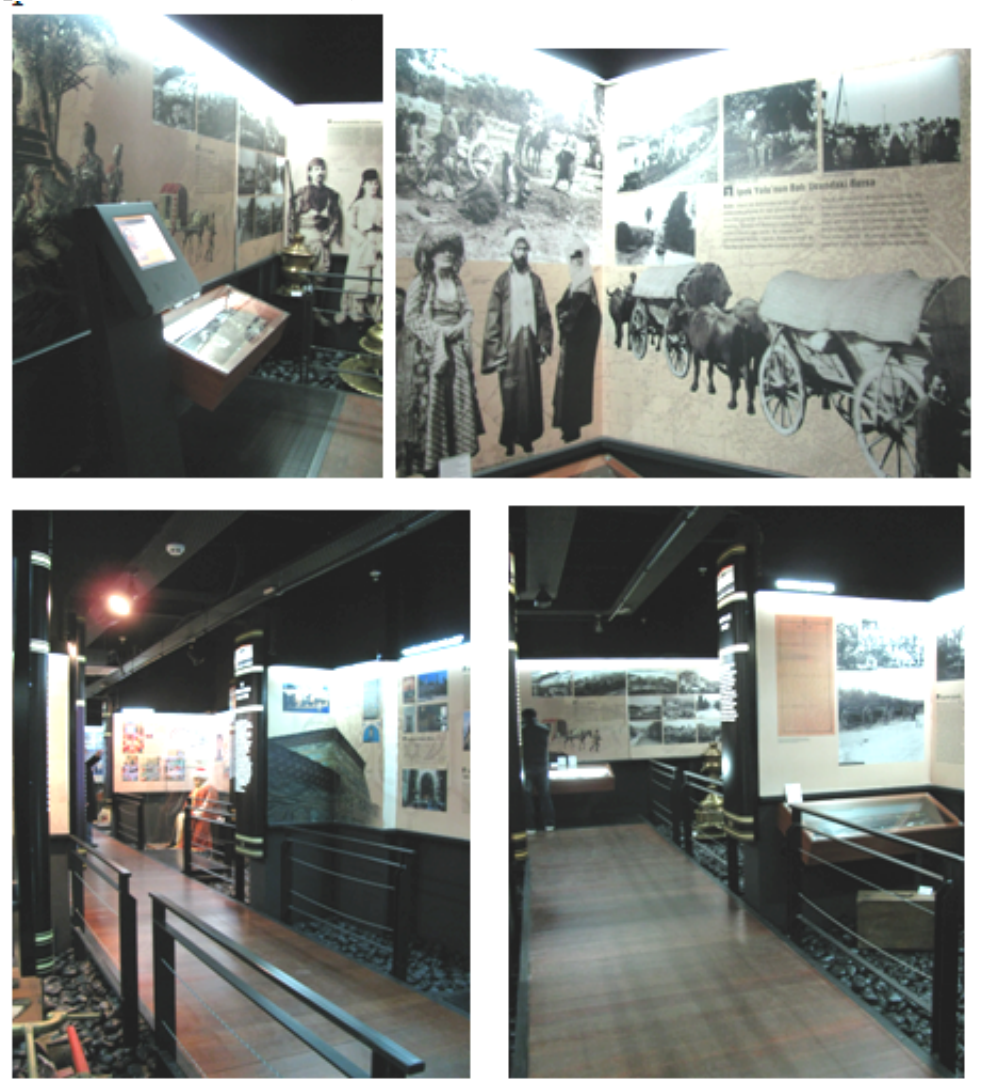

Figure 2: Bursa City Museum, Exhibition Area at Entrance Floor

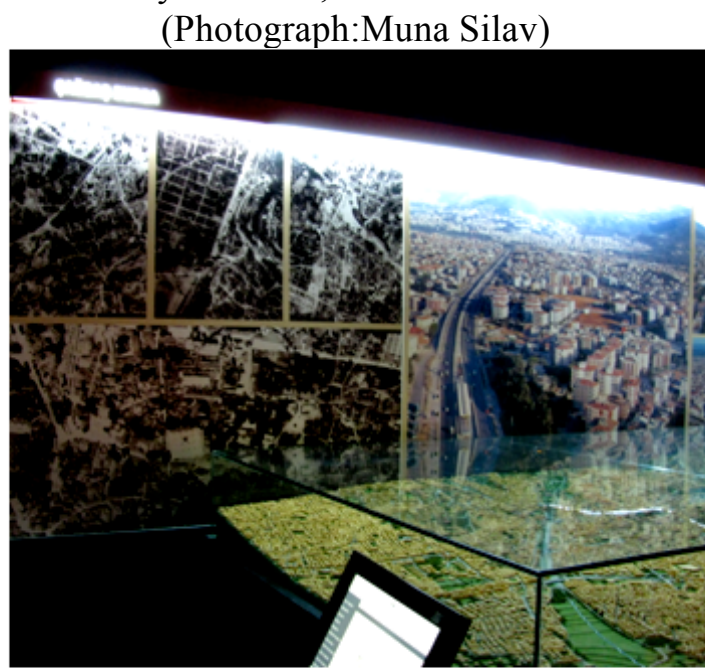

Figure 3: Bursa City Museum, Topographic Maket at Entrance Floor (Photograph:Muna Silav)

In the basement of the museum, there are parts of "Handicraft Bazaar, Silk city of Bursa, and Producing Bursa." In the Handicrafts Bazaar, the coachman, blacksmith, saddle sellers, hand- 
printed head scarf maker, cutler, coppersmith, tinsmith, plumber, carpenter, pad seller, basketware, kebab seller, silk seller, and towel seller display original objects on (Figure 4).
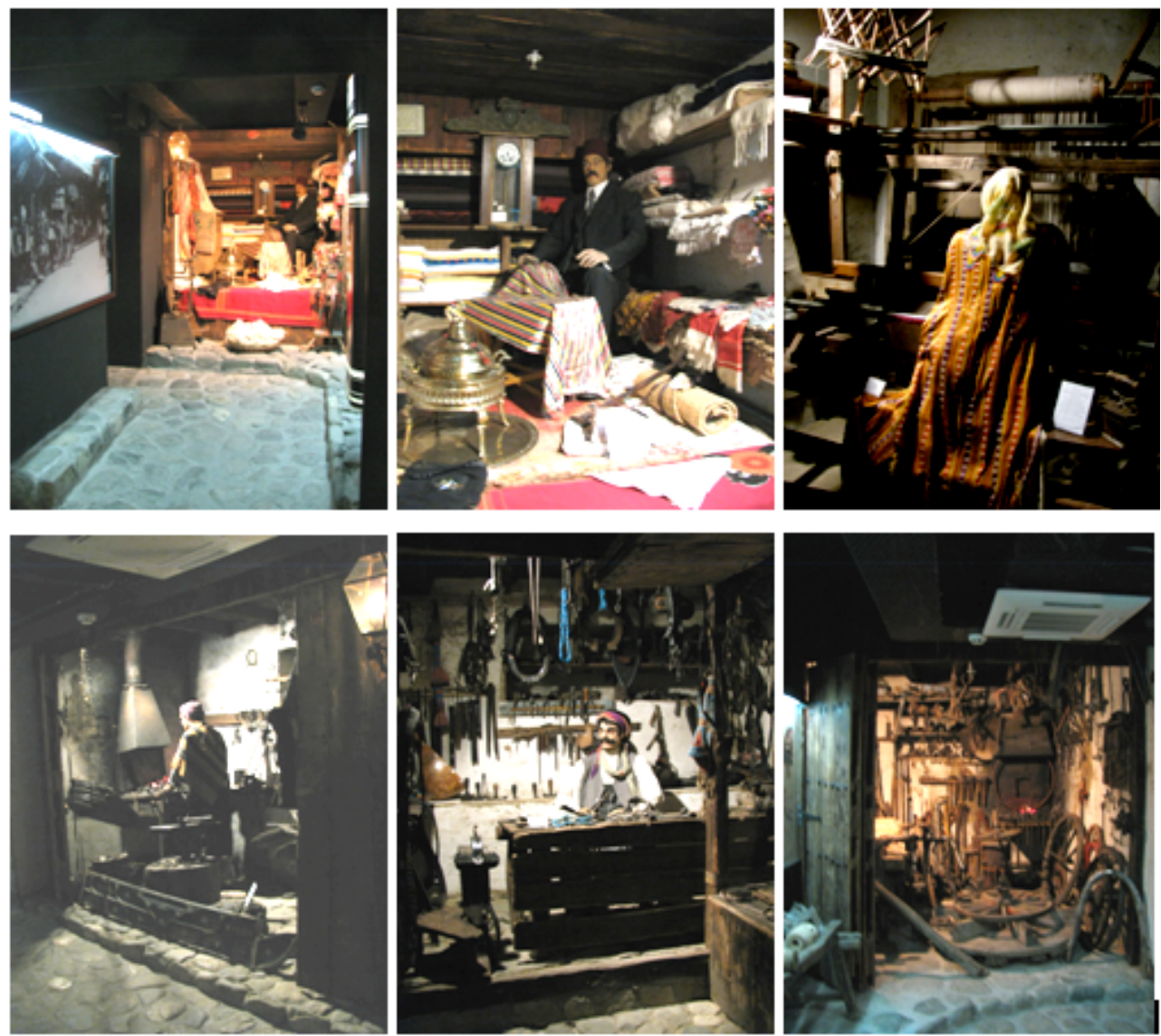

Figure 4: Bursa City Museum, Handicrafts Bazaar Basement Floor

(Photograph:Muna Silav)

In the upper floor of the museum, in the "The Life and culture of Bursa" gallery, life stories of important people in this city and traditions are being described and displayed. Moreover, there are places such as a library that researchers can take advantage of, a reading room, administrative units, and a lounge where meetings can be hold. Exhibits that are opened in the three museum exhibition hall are presented at regular intervals. These activities; makes informed individuals about a common past, strengthens feelings of solidarity and unity between them, provides continuity of traditions and social experiences throughout the history. The importance of the Bursa city museum is great in the field of transferring historical and cultural heritage to future generations, providing individuals to realize their creativity and sense of discovery.

Considered one of the examples of contemporary museums the Bursa City Museum, in addition to exhibiting works of art and traditional products, activities for educational purposes are performed, too. As examples for the work of education in Bursa City Museum activities such as Hacivat and Karagöz puppet making and line working, which are descriptor of museum building and objects to the students, are being applied. It can be regarded as highly important steps that should be heeded in the field of transferring these to the younger generation in terms of museums and especially for traditional crafts. Bursa City Museum has become the center of cultural activity with the participation of individuals to the activities (Anonymity, 2008) 
Bursa Metropolitan Municipality, applied for candidacy in favor of the award named "2006 European Museum Award" which is given by European Museum Forum for the "Bursa City Museum". In the award ceremony, which is held in Lisbon, Portugal by European Museum Forum in May 2006, metropolitan Municipality of Bursa, Bursa City Museum became one of Europe's award-winning museums and has proven that it is a museum for European standards. It is accepted that Bursa City Museum has become an important point for the international communication thanks to being a member of the "European Association of Museums" http://www.bursakentmuzesi.com/

\section{CONCLUSIONS}

City museums convey the city's history from the beginning to present in terms of social, economic, and cultural items; moreover, they bring together all sorts of data about the city. Individuals are acquainted with the cultural values of cities, and they recognize the city and it's around with visits to museums. Bursa City Museum provides a more closely recognition of the city to citizens organizing conferences, documentaries, festivals, private temporary exhibitions citizens. On one hand, tissues of the historic city join the social life of dwellers; on the other hand, it contributes to the revival of cultural tourism. Bursa City Museum is a museum that improves, preserves itself and it is a museum that easy to read. It is an institution that supports the city's cultural life as well as supporting education and communication. To let us see our future we should know our history, and to know our history we should visit our museums.

\section{REFERENCES}

Anonymity (2008). Prusa'dan Günümüze Bursa. Bursa Büyükşehir Belediyesi. Elma Basım. İstanbul.

Cengiz, İ. (2009). The Living Museum. Bursa Büyükşehir Belediyesi. Elma Basımevi. Bursa. Collins, A.M. (1995). The city is The Museum. Museum International No:187 Vol.XLVII No:3. 30-34.

Eldem, N. and Gökhan, E. (1992). Müze ve Müze Mimarisi Üzerine. Tasarım. 30. 108-113. Madran, B. (2001). Kent, Toplum, Müze Deneyimler- Katkılar. Tarih Vakfi. İstanbul.

Madran, E. (2000). Kent Belleğinin Oluşumunda Yapılar: Kaynaklar ve Yorumlar. Müzecilikte Yeni Yaklaşımlar. Tarih Vakfı. İstanbul. 81.

Silier, O. (2010). Dünyada ve Türkiye'de Kent Müzeleri. Ege Mimarlık. 74. 16-21.

Tezcan Akmehmet, K. and Ödekan, A. (2006). Müze Eğitiminin Tarihsel Gelişimi. İTÜ Dergisi/b Sosyal Bilimler. 3,1. 47-58.

Vardar, N.A. (1996). Müze ve Müzecilik Kültürü. Kuruluşunun 150.Yılında Türk Müzeciliği Sempozyumu III Bildiriler. Ankara: Genel Kurmay Askeri Tarih ve Stratejik Etüt Başkanlığı Yayinlar1. 16-21.

http://www.bursakentmuzesi.com/ 